\title{
Pharmacological immunomodulation enhances peripheral nerve regeneration ${ }^{1}$
}

\author{
Ana Paula Inoe ${ }^{2 *}$, Francisco Carlos Pereira ${ }^{3}$, Angelo João Stopiglia ${ }^{4}$ and \\ Ciro Ferreira Da-Silva ${ }^{5}$
}

\begin{abstract}
Inoe A.P., Pereira F.C., Stopiglia A.J. \& Da-Silva C.F. 2007. Pharmacological immunomodulation enhances peripheral nerve regeneration. Pesquisa Veterinária Brasileira 27(9):363-369. Departamento de Anatomia, Instituto de Ciências Biomédicas, Universidade de São Paulo, Cidade Universitária, Av. Prof. Lineu Prestes 2415, São Paulo, SP 055508-900, Brazil. E-mail: ana.paula@unipar.br

To assess the effect of N-Acetylmuramyl-L-Alanyl-D-Isoglutamine MDP topically administrated on the regenerating peripheral neurons, twelve male $\mathrm{C} 57 \mathrm{BL} / 6 \mathrm{~J}$ adult mice were equally distributed into three groups. Four mice underwent unilateral sciatic nerve transection and polyethylene tubulization, with a $4 \mathrm{~mm}$ gap between the proximal and distal nerve stumps and were implanted with collagen + PBS (COL). Other four animals underwent the same surgical procedure but received collagen + MDP (COL/MDP) inside the prosthesis. Four animals were not operated and served as control group (NOR). After 4 weeks, the regenerated nerve cables were processed for total myelinated axon counting and myelinated fiber diameter measurement. The L5 dorsal root ganglion (DRG) was also removed and sectioned for sensory neurons counting and measurement. The results revealed significant difference $(\mathrm{p}<0.05)$ in axonal counting among the groups NOR $(4,355 \pm 32), \operatorname{COL}(1,869 \pm 289)$ and $\operatorname{COL} / \mathrm{MDP}(2,430 \pm 223)$. There was a significant reduction in the axonal diameter in the operated groups $(\mathrm{COL}=3.38 \mu \mathrm{m} \pm 1.16$ and $\mathrm{COL} / \mathrm{MDP}=3.54 \mu \mathrm{m} \pm 1.16)$ compared to NOR $(6.19 \mu \mathrm{m} \pm 2.45)$. No difference was found in the number of $D R G$ neurons between the experimental groups $(\mathrm{COL}=564 \pm 51 ; \mathrm{COL} / \mathrm{MDP}=514 \pm 56)$, which presented fewer sensory neurons compared to NOR $(1,097 \pm 142)$. Data obtained indicate that locally applied MDP stimulates peripheral nerve regeneration in mice.
\end{abstract}

INDEX TERMS: N-Acetylmuramyl-L-Alanyl-D-Isoglutamine MDP, nerve regeneration, drug effect, sciatic nerve, surgery.

RESUMO.- [Imunomodulação farmacológica aumenta a regeneração de nervos periféricos.] Para avaliar o efeito do $\mathrm{N}$ Acetilmuramil-L-Alanil-D-Isoglutamina administrado topicamente em neurônios periféricos em regeneração, doze camundongos $\mathrm{C} 57 \mathrm{BL} / 6 \mathrm{~J}$ machos adultos foram igualmente separados

\footnotetext{
${ }^{1}$ Received on May 2, 2007.

Accepted for publication on September 13, 2007.

${ }^{2}$ Universidade Paranaense, Praça Mascarenhas de Moraes s/n, Umuarama, PR 87502-210, Brazil. "Corresponding author: ana.paula@unipar.br

${ }^{3}$ Depto Anatomia, Instituto de Ciências Biomédicas, Universidade de São Paulo (USP), Av. Prof. Lineu Prestes 2415, Cidade Universitária, São Paulo, SP 055508-900, Brazil.

${ }^{4}$ Depto Cirurgia e Anestesiologia Veterinária, Faculdade de Medicina Verterinária e Zootecnia, USP, Av. Prof. Dr. Orlando Marques de Paiva 87, Cidade Universitária, São Paulo, SP 05508-270, Brazil.

${ }^{5}$ Depto Biologia Celular e do Desenvolvimento, Instituto de Ciências Biomédicas, USP, Av. Prof. Lineu Prestes 1524, Cidade Universitária, São Paulo, SP 05508-900, Brazil.
}

em três grupos. Quatro animais sofreram transecção unilateral do nervo ciático que foi ancorado no interior de um tubo de polietileno, mantendo-se $4 \mathrm{~mm}$ de distância entre as extremidades dos nervos e receberam colágeno + PBS $(\mathrm{COL})$ dentro do tubo. Outros quatro animais sofreram o mesmo procedimento cirúrgico, porém receberam colágeno + MDP (COL/MDP) no interior da prótese. Quatro animais não foram operados e serviram como controle de normalidade (NOR). Após quatro semanas, os cabos de regeneração foram coletados para determinação do número de axônios mielínicos e da média do diâmetro das fibras mielínicas regeneradas. 0 gânglio da raiz dorsal L5 também foi coletado para contagem e mensuração dos neurônios sensitivos. Os resultados revelaram diferença significativa no número de axônios entre os grupos NOR $(4355 \pm 32)$, $\operatorname{COL}(1869 \pm 289)$ e COL/MDP (2430 \pm 223$)$. Houve redução significativa no diâmetro das fibras mielínicas nos grupos que receberam as próteses tubulares $(\mathrm{COL}=3,38 \mu \mathrm{m} \pm 1,16 \mathrm{e} \mathrm{COL} /$ 
$\mathrm{MDP}=3,54 \mu \mathrm{m} \pm 1,16)$ quando comparados ao grupo NOR $(6,19 \mu \mathrm{m} \pm 2,45)$. $O$ número de neurônios não diferiu entre os grupos experimentais $(\mathrm{COL}=564 \pm 51$ e $\mathrm{COL} / \mathrm{MDP}=514 \pm 56)$, os quais apresentaram menor número de neurônios sensitivos em relação ao grupo não operado $(\mathrm{NOR}=1097 \pm 142)$. Os dados obtidos indicam que a aplicação local do MDP estimula a regeneração de nervos em camundongos.

TERMOS DE INDEXAÇ̃̃O: N-acetilmuramil-L-alanil-D-isoglutamina MDP, regeneração nervosa, efeitos de drogas, nervo ciático, cirurgia.

\section{INTRODUCTION}

A section or crush injury, caused by a traumatism of a peripheral nerve still constitutes a single but worrying condition, resulting in motor and/or sensitive function loss creating an impossibility to accomplish several activities. As the opposite of other cells from an animal organism, the neurons do not replicate. On this perspective, the regeneration of an injured nerve is deficient and disappointing and inspires, somehow, many experiments in surgery, neurology and neurobiology field with the purpose to increase the regeneration of nervous system. Tubulization repair technique described in XIX century constitutes an option in cases of small gaps. This technique is useful to evaluate in vivo the effect of several substances on peripheral nerve regeneration, and it has been used by many authors associated to drugs in attempts to improve axonal regeneration (Battiston et al. 2005).

After injury, an inflammatory reaction involving macrophages, results in phagocythosis of myelin debris and cytokines secretion, indicating a fundamental role of this process on regeneration. When the inflammatory reaction is insufficient, tissue regeneration occurs slowly, and it is incomplete many times. An intervention in the repairing process is possible through the introduction of inflammatory cells or by an induction of inflammatory reaction which accelerate tissue regeneration (Stoll et al. 1989, Kiefer et al. 2001, Ousman \& David 2001). N-Acetylmuramyl-L-Alanyl-DIsoglutamine (MDP) is a minimum structural unit responsible for the immunoadjuvant activities of bacterial cell wall peptidoglycans in a variety of species. Among other actions, MDP stimulates the phagocytic activity of macrophages, microglia and Schwann cells, facilitating the removal of myelin without affecting the expression of pro-inflammatory cytokines. Local MDP injection into the site of spinal cord injury was shown to improve histological and behavioral outcome (Pearse et al. 2001).

The tubulation model of nerve repair was used to study the effects of MDP locally administered immediately after injury of sciatic nerve, in adult animals.

\section{MATERIALS AND METHODS}

Twelve male C57BL/6J, adult mice, weighing 27.3 to $29.4 \mathrm{~g}$ were studied. During observation time, animals were individually housed in appropriate compartments with 12-h light-dark cycle and temperatures of $21^{\circ} \mathrm{C}$, receiving food and water ad libitum. After i.p. injection of Avertin $(0.5 \mathrm{~g}$ tribromoethanol dissolved with $0.25 \mathrm{~g} \mathrm{2-}$ methyl-2-butanol in $19.5 \mathrm{ml}$ water) $0.02 \mathrm{ml} / \mathrm{g}$ body weight, the left sciatic nerve was exposed and transected at midthight. The proximal and distal stumps were sutured with a single 10.0 nylon suture, into a polyethylene (PT) nerve guide (Clay Adams, length of $6 \mathrm{~mm}$, inner diameter of $0.76 \mathrm{~mm}$, Fig. 1A) leaving a $4 \mathrm{~mm}$ gap (Fig.1B).

Animals were separated in three groups named: $\mathrm{COL}, \mathrm{COL} / \mathrm{MDP}$ and NOR. In group COL, PT was filled with $2 \mu \mathrm{l}$ of a purified solution of collagen type I $(2.4 \mathrm{mg} / \mathrm{ml}$ VitrogenÒ, (Collagen Corporation, Palo Alto, CA, USA). N-acetylmuramyl-L-alanyl-D-isoglutomine (MDP) (Sigma Chemical Co, St Louis, USA) was diluted in $1 \mathrm{ml}$ of saline solution, obtaining a $2 \mathrm{mM}$ concentration. After adding an equal volume of collagen, the final concentration of the MDP was of $1 \mathrm{mM}$. Animals from group COL/MDP were implanted with collagen and MDP and the four remaining (NOR) were not operated and were used as normal control.

After a 4 weeks survival time, the mice were anesthetized and perfused transcardially with $5 \mathrm{ml}$ of heparinized saline solution $(\mathrm{NaCl}$ $0.9 \%$ ), followed by $150 \mathrm{ml}$ of Karnovsky's fixative solution. The PT containing the regenerated nerve cable (RC, Fig.1C) were dissected out, and from group NOR a fragment from the sciatic nerve was collected. The fragments were post-fixated in osmium tetroxide solution ( $2 \%$ phosphate buffer $0.1 \mathrm{M}$ and $\mathrm{pH} 7.3)$ and processed for Epon embedding (EPON 812, Tousimis) in order to obtain onemicrometer-thick transverse sections and stained with toluidine blue. The number of myelinated axons at the middle point of RC was determined with a computer controlled system (Biographics, Winston Salem, NC, USA). Data from the number of myelinated nerve fibre were determined from sciatic nerves of control animals. Axonal diameter were measured from three distinct fields using a computerized morphometric analysis system (SigmaScan Pro, Jandel Corporation, 5.0 version, San Raphael, CA, USA).

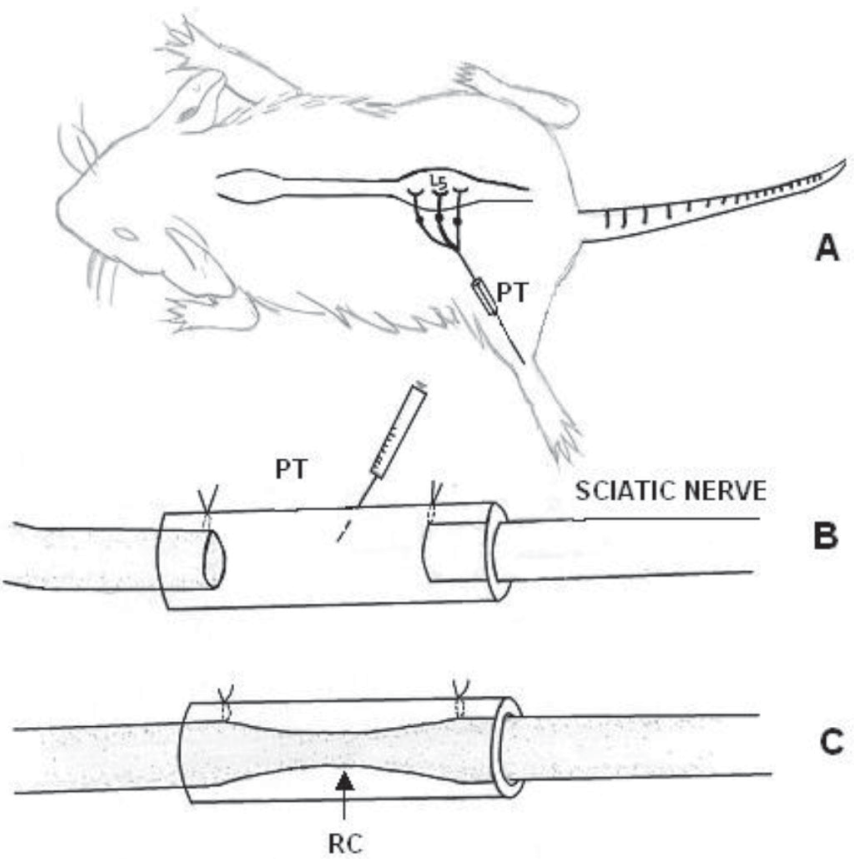

Fig.1. Schematic representation of the experimental model: A) Polyethylene tube (PT) at the middle point of sciatic nerve; it represents spinal ganglions that contribute to the sciatic nerve formation, emphasizing L5 dorsal root ganglion. B) Details from the implanted tube with proximal and distal segments from the sciatic nerve, with a $4 \mathrm{~mm}$ gap; the tube being filled with collagen or collagen and MDP. C) Four weeks after the surgery the presence of the regeneration cable was observed (RC). 


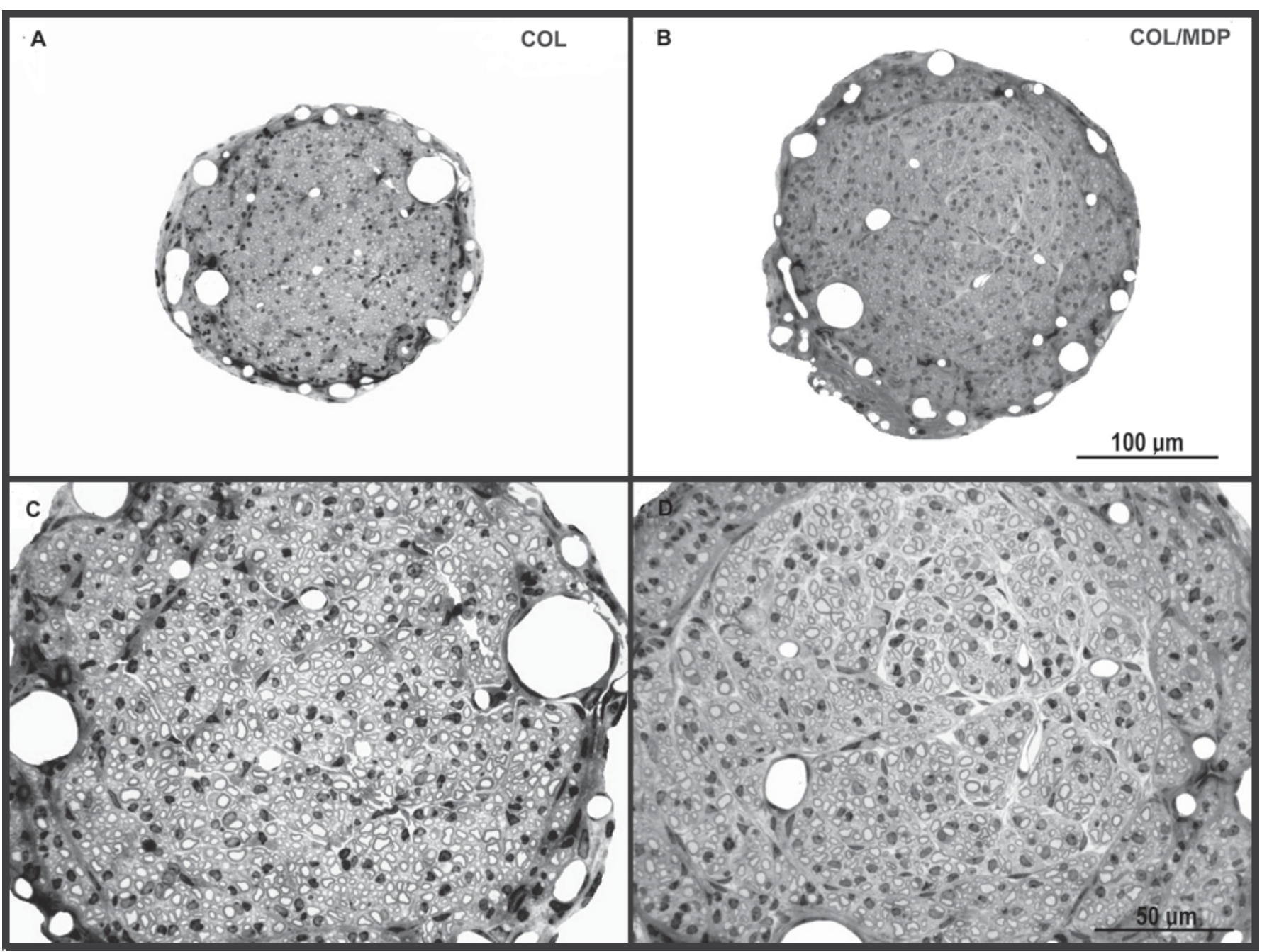

Fig.2. Cross section at the midpoint of regenerated sciatic nerve cables after polyethylene tubulization implanted with collagen (A and $\mathrm{C}$ ) or collagen + MDP (B and D). Myelinated fibers organized into small bundles. Scale bars: A, B $=100 \mu \mathrm{m} ; \mathrm{C}, \mathrm{D}=50 \mu \mathrm{m}$.

L5 dorsal root ganglion, attached to the sciatic nerve was also removed (Fig.1A), kept in Karnovsky's solution for 24 hours at $4^{\circ} \mathrm{C}$ and embedded in histo-resin. Longitudinal sections were cut serially $(5 \mathrm{~mm})$ and stained with toluidine blue $(0.25 \%)$ followed by fucsin solution. They were analyzed for their aspect and disposition of sensitive neurons. The number of neurons that survived from axotomy were determined in a compound microscope by counting all stained cells that showed a nucleolar profile in one of each ten cuts of the ganglion. From the same cuts images were captured with a digital camera and with a computerized morphometric analysis system (SigmaScan Pro, Jandel Corporation, 5.0 version, San Raphael, CA, USA) the area of the cellular bodies from the neurons that showed an evident nucleolus was measured.

Data of number of myelinated nerve fibres and number of neurons were submitted to an analysis of variance and the treatment means were compared by Tukey procedure in a $5 \%$ significance level.

\section{RESULTS}

\section{Morphological observations}

Transverse sections of the regenerated nerve cables showed myelinated fibers organized into small bundles surrounded by perineurium with the same morphologic aspect in groups COL and COL/MDP (Fig.2). The myelinated fibers had different diameter and Schwann cells could be seen. The fragments from the sciatic nerve collected in group NOR presented the aspect of a normal nerve. Dorsal root ganglia had similar structure in all experimental groups with neurons, round cells with evident nucleus, disposed preferentially in the periphery.

\section{Morphometric results}

Axonal counting. Animals from control group had significantly more myelinated axons $(4,355 \pm 32)$ when compared to operated groups (Table 1). There was a statistical difference $(\mathrm{P}<0.05$, Tukey test) between the group implanted with collagen $+\operatorname{MDP}(2,430 \pm 223)$ and the group that received collagen alone $(1,869 \pm 289)$.

Number of sensitive neurons in L5 dorsal root ganglion. There was a large reduction in the number of sensitive neurons from L5 dorsal root ganglion in tubulized groups (COL and COL/MDP) when compared to non-operated group (NOR) (Table 
Table 1. Mean, standard deviation and differences between treatment for the number of myelinated axons and sensitive neurons found in the $L_{5}$ dorsal root ganglion of mice implanted with collagen solution (COL) or collagen + MDP (COL/MDP) after a four-week survival time and in non operated mice (NOR)

\begin{tabular}{ccc}
\hline Group & Number of myelinated axons & Number of neurons \\
\hline COL & $1,869.75 \pm 289.46^{\mathrm{c}}$ & $564.25 \pm 51.47^{\mathrm{b}}$ \\
COL/MDP & $2,430.5 \pm 223.86^{\mathrm{b}}$ & $514.2556 .16^{\mathrm{b}}$ \\
NOR & $4,355 \pm 32.57^{\mathrm{a}}$ & $1,097.75 \pm 142.78^{\mathrm{a}}$
\end{tabular}

Means followed by the same letter are statistically equal by Tukey test $(\mathrm{P}<0.05)$.

Table 2. Means and standard deviations of axonal diameter $(\mu \mathrm{m})$ and sensitive neurons area $\left(\mu \mathrm{m}^{2}\right)$ found in $\mathrm{L} 5$ dorsal root ganglia from mice implanted with polyethilene tubes with collagen solution (COL) and collagen + MDP (COL/MDP), four weeks after the surgery and in non operated mice (NOR)

\begin{tabular}{ccc}
\hline Treatment & Axonal diameter $(\mu \mathrm{m})$ & Area of neurons $\left(\mu \mathrm{m}^{2}\right)$ \\
\hline COL & $3.38 \pm 1.16$ & $518.62 \pm 145.71$ \\
COL/MDP & $3.54 \pm 1.16$ & $543.86 \pm 143.73$ \\
NOR & $6.19 \pm 2.45$ & $487.97 \pm 146.35$
\end{tabular}

1). The number of neurons in groups $\mathrm{COL}$ and $\mathrm{COL} / \mathrm{MDP}$ present in the L5 spinal ganglion was statistically similar.

Axonal diameter. Tubulization technique was folowed by a reduction of the mean size of axons (Table 2). In groups COL and COL/MDP there were several small sized axons (44.34\% and $38.5 \%$, respectively) and $5.76 \%$, in group NOR. The fibers with diameters between 2 and $5 \mu \mathrm{m}$, were observed in all groups with a higher incidence: COL (51.45\%), COL/MDP $(57.32 \%)$ and NOR (45.54\%). The control group presented several myelinated fibers with diameters between 5 and $9 \mu \mathrm{m}$ (40.35\%), a fact that was not observed in COL and COL/MDP which showed $4.2 \%$ and $4.25 \%$, respectively. The presence of myelinated fibers with a diameter greater than $9 \mu \mathrm{m}$ was only observed in control group (8.37\%).

Sensitive neurons morphometry. Means and standard deviation from sensitive neurons areas from L 5 dorsal root ganglion can be observed in Table 2. Cellular bodies of sensitive neurons on the $\mathrm{L} 5$ dorsal root ganglion from animals from group COL had area values distributed between 100 and $1.350 \mu \mathrm{m}^{2}$; the sensitive neurons areas in group COL/MDP were between 100 and $1,750 \mu \mathrm{m}^{2}$, and group NOR had values distributed between 50 and $1,600 \mu \mathrm{m}^{2}$.

\section{DISCUSSION}

Several substances have been characterized as immunomodulators for the nervous system in recent years, including $\mathrm{N}$-Acetylmuramyl-L-Alanyl-D-Isoglutamine. It is known MDP can be considered a functional lipopoly-saccharides analogue (LPS) (Hoffmann et al. 1999). Among other actions, MDP stimulates the phagocytic activity of macrophages, microglia and Schwann cells (Parant et al. 1992, Ringerbach et al. 1998). Local MDP injection into the site of spinal cord injury was shown to improve behavioral outcome. Histologically, there was an increase in the number of myelinated axons from lateral motor tracts, greater number of activated macrophages/microglia (ED1+) at the lesion site, being the majority Mac1 +, indicating they were actively involved in phagocytosis (Pearse et al. 2001). Some of the benefic properties mentioned by authors include the phagocytosis stimulation by immunocompetent cells, facilitating the myelin removal without affecting pro-inflammatory cytokines expression and unleash the suppressor cytokines expression like IL-10. MDP intrafascicularly injected into crushed rat sciatic nerve activated macrophages infiltrating into damaged nerve and the macrophages supported elongation of regenerating axon (Fukuyama et al. 1998).

The wallerian degeneration (Ramón y Cajal 1991) is the response from the nervous system to axonal lesion that involves cellular and molecular activities being coordinated by a complex net of cytokines that also contributes to macrophages recruitment and activation and, consequently, to macrophages dependent functions like myelin removal by phagocytosis (Rotshenker 1997).

In peripheral nervous system the decrease of the response from these cells in injured nerves has been associated with the decrease of axonal regeneration (Dahlin 1995, Kiefer et al. 2001). Macrophages produce proteins with positive effects on optical nerve regeneration and the effects of macrophages can be optimized by the timing of their activation (Yin et al. 2003).

Blood-nerve barrier is less tight than hemato-encephalic barrier, allowing the rapid influx of macrophages after a lesion in a peripheral nerve (Kiefer et al. 2001). The lesion itself breaks the blood-nerve barrier facilitating the macrophages cross to the site of injury. Macrophages are recruited from blood vessels since the second day after the lesion $(\mathrm{ED} 1+)$ (Stoll et al. 1989). These phagocytes rapidly remove myelin debris (Stoll et al. 1989, Reichert et al. 1996, Hirata et al. 1999) that have neurite growth inhibitors, like myelin associated glycoprotein, facilitating nerve regeneration (Perry \& Brown 1992) and release cytokines and growth factors (Lindholm et al. 1987, Mallat et al., 1989, Fukuyama et al. 1998, Kiefer et al., 2001). One of the macrophagic activation mechanisms occurs through tumoral necrosis factor (TNF-á) (Moonis et al. 1992) that is one of the first cytokines synthesized by Schwann cells during the wallerian degeneration process (Saada et al. 1996, Shamash et al. 2002). TNF-á stimulates the macrophages directly (Saada et al. 1996) and induces the production of granulocytes and macrophages colonies stimulator factor (GMCSF) by fibroblasts, promoting macrophages activation. MDP is capable of inducing the formation or stimulates cells to produce several cytokines like TNF-á (Wolfer et al. 2002) contributing indirectly to the macrophagic activation. Thus, one of the prime actions for MDP is macrophages activation.

Inside the nerve, the macrophages secrete several proinflammatory cytokines including TNG-á, IL-1á, IL-1â, IL-6 and the anti-inflammatory cytokines TGF-â1 and IL-10, regulating the inflammation (Kiefer et al. 2001, Schrijver et al. 2001). TNFá, IL-1á and IL-1â induce low levels of NGF production by fibroblasts (Hattori et al. 1993) and IL-6 e IL-10 by macrophages (Saada et al. 1996). IL-10 reduces the production of all inflammatory cytokines and itself production regulating wallerian degeneration (Be'eri et al. 1998, Shamash et al. 2002). 
Macrophages recruitment is associated with the increase of axonal growth promoter molecules expression like NGF (Brown et al. 1991), theses cells seem to stimulate Schwann cells to produce NGF through IL-1 release (Lindholm et al. 1987, Nelson et al. 2002) and their neutralization inhibits nerve regeneration. Cytokines can indirectly regulate neuronal survival and axonal growth through NGF regulation (Shamash et al. 2002). They play key physiological role in nerve repair. Even exact mechanisms of MDP cellular activation and their analogues have not being revealed (Wolfer et al. 2002), MDP could act supporting axonal regeneration through direct or indirect macrophages activation. MDP for its own characteristics in the immunological system stimulation, acting especially in macrophages, and in cytokines stimulation, could accelerate the wallerian degeneration process and peripheral nerve regeneration. An interesting aspect to be considered is the efficient myelin removal through phagocytosis by macrophages that would accelerate the regeneration process with more rapid muscle reinnervation, avoiding atrophy and increasing the chances for functional recovery.

The objective of this report was restricted to the evaluation of MDP effect on peripheral nerve regeneration with tubulization technique in male, adult $\mathrm{C} 57 \mathrm{BL} / 6 \mathrm{~J}$ mice, and immediate repaired with the tubulization technique. None of the mechanisms above mentioned were verified. However, the several mechanisms throughout MDP would act in nerve regeneration need to be better elucidated.

Morphological evaluation did not allow verifying the macrophages infiltration and proliferation in cuts from the midpoint of RC. The utilization of techniques, as for example, immunohistochemistry, antigens (Yin et al. 2003) and confocal microscopy, would be better adequate to the macrophages visibility. Survival times used by the authors were two, seven, fourteen and twenty-one days. The four weeks time of survival used did not allow evaluating the presence of macrophages because the influx of macrophages begins in the first 24 hours after axotomy and reaches the peak in 14 to 21 days (Avellino et al. 1995). Thus, the medium portion of regeneration cables evaluation through techniques and survival times better adequate to the macrophages observation, as quantity analysis, would give worthy information about MDP action on macrophages.

The tubulization technique is a valuable model in experimental studies once there are no better methods allowing studying the effect of substances that incite cellular or molecular alterations in the regeneration nerve microenvironment (Fields et al. 1989, Battiston et al. 2005). We used here the tubulization model of nerve repair to study the MPD effects on peripheral nerve regeneration in adult animals.

The 4 weeks survival time to evaluate the regeneration process, was based in the fact there are not variations on axonal counting found in the regeneration cable from sectioned sciatic nerve and repaired with tubulization technique at four and six weeks after the tubulization (DaSilva et al. 1985).

Histological aspect in $\mathrm{RC}$ revealed small fascicules collection united by conjunctive tissue (perineurium) (Fields
\& Ellisman 1986). This aspect denominated compartmentation reveals the ability of the regenerating nerve, which forms these compartments around the regenerating projections, repairing one of the nerve-blood barriers (Mackinnon et al. 1984).

Animals implanted with PT had less myelinated axons than non operated animals. Sciatic nerve transection in adult male mice $\mathrm{C} 57 \mathrm{BL} / 6 \mathrm{~J}$, resulted in significant reduction from the number of regenerated myelinated axons inside the tubular prosthesis (Da-Silva et al. 1985, Pereira et al. 1998). Animals who received MDP associated with collagen presented more myelinated axons when compared to the ones who received collagen only, evidencing MDP stimulating effect on peripheral nerve regeneration.

Morphometrical analysis from myelinated axons in the tubulized groups (COL and COL/MDP) showed a reduction in axonal diameter when compared to the non operated group (NOR). Several authors observed that myelinated axons regenerated inside the tubular prostheses have inferior diameters than the ones seen in normal nerves (Le Beau et al. 1988), even after an observation period of 10 months (Fields \& Ellisman 1986). In our data, it is evident the reduction of regenerated axons diameters inside the tubular prostheses. Number of myelinated axons and diameter are parameters that measure the regenerating axon maturation (Lundborg 1988). These parameters were also used by other authors to evaluate nerve regeneration (Fields \& Ellisman 1986).

The number of sensitive neurons from L5 dorsal root ganglion suffered significant loss in the groups with sciatic nerve transection. Such result is according to other studies who evaluated dorsal root ganglion in several animal species (Aldskogius \& Risling 1981, Liss et al. 1996). After a lesion of a peripheral nerve, neuronal death can occur because of the loss of neurotrophic factors support derived from the target organ, including NGF an important factor in the sensitive neurons maintenance that prevent cellular death (Liss et al. 1996). When Schwann cells loose contact with axons they start releasing NGF and BDNF after a period (Meyer et al. 1992). These proteins release are not fast enough to avoid death of sensitive neurons that depends on such factors to survive. Motor neurons have a CNTF source immediately after the trauma and can survive to it; sensitive neurons, in the other hand, should be more sensitive to the trauma, once the trophic support is dependent to the later factors synthesis by Schwann cells (Lainetti et al. 1995). Nerve transection with partial amputation of axons resulted in significant loss of sensitive neurons number on L5 dorsal root ganglion in both operated groups, which had no statistical difference between them in this parameter. Sciatic nerve transection resulted in a poor axonal regeneration in mice C57BL/6J (Lu et al. 1994), probably because of the loss of $40 \%$ of sensitive cells from dorsal root ganglion after axotomy, becoming a suitable experimental model to evaluate the effects from exogenous substances in peripheral nerve regeneration (Lainetti et al, 1995). Results obtained here from the neurons that survived to the lesion in group that received MDP showed a large cellular loss, indicating that MDP did not have a protective action in sensitive neurons after sciatic nerve transection. Sciatic nerve 
resection, in adult animals, results in 15 to $36 \%$ loss of cells from L4-L6 dorsal ganglions (Aldskogius \& Risling 1981, Myles et al. 1992, Liss et al. 1996). There is a larger loss of sensitive neurons at proximal resections compared to the distal resections in the nerve. At proximal lesions the response of pericarium is more intense and can exceed its synthesis capacity resulting in neuronal death (Ygge 1989).

Cellular body area increase could have happened because of the chromatolysis process in response to nerve transection. After axotomy, the cellular body reacts trying to replace the axoplasmatic volume lost, passing through many alterations known as chromatolysis. The nucleus becomes eccentric and develops evident nucleolus, besides occurring the endoplasmatic rough reticules increase and become diffused on the cytoplasm (Nissl's corpuscle). The typical response from cellular body to axotomy includes the increase of cell size associated with the increase of proteins synthesis from cellular structure that are important to axonal regeneration (Mcllwain $\&$ Hoke 2005). After that, there is a reduction of these proteins synthesis and cells can suffer size regression. This reaction starts within 24 hours after the lesion, becoming maxima in one to three weeks (Mcllwain \& Hoke 2005). Alterations from cellular body size make difficult to establish the affected populations by the nerve transection, reparation method, as well as the administrated drug effect.

Morphologic evaluation of longitudinal cuts from dorsal ganglions did not allow observing chromatolysis morphological characteristic alterations. Although toluidine blue constitutes an adequate staining to evidence Nissl's corpuscle, other staining could provide better results. Probably at the evaluation time here used, many of the components in the cytoplasm that could evidence the chromatolysis process were absent or present in small quantity. Thus, after staining, it was not possible to evidence the chromatolysis morphological alterations. The small percentage of neurons that showed an increase of the area, could also difficult the demonstration of chromatolysis in the observed cut. Light optical microscopy could not have been sensible sufficient to detect this process. On the other hand, morphometrical evaluation with objective data, that showed an increase in neuronal area, was more precise to evaluate the process. The results here obtained, from the size of the neurons, could not establish a specific population of sensitive neurons affected by trauma. The same results were obtained by other authors (Aldskogius \& Risling 1981).

New studies to elucidate MDP action mechanisms on myelinated and non-myelinated fibers, with several survival times, are necessary to better evaluate its role on peripheral nerve regeneration.

\section{CONCLUSIONS}

Quantitative data analysis obtained with MDP or collagen after nerve lesion and tubulization technique repair in adult mice allowed to conclude:

- Nerve transection followed by the repair with tubulization technique resulted in the reduction of regenerated myelinated axons numbers compared to intact nerve. The use of local MDP immediately after the lesion increased the axonal regeneration process when compared to the use of collagen alone.

- Tubulization technique with MDP or collagen was folowed by a reduction of the mean size of axons, compared to normal nerves.

- There was a loss of sensitive neurons in dorsal root ganglion that did not reach a specific population when considered the neurons area. The results show that MDP and collagen did not have a protective action on sensitive neurons survival after axonal transection.

Acknowledgements.- To FAPESP for the support of the project.

\section{REFERENCES}

Aldskogius H. \& Risling M. 1981. Effect of sciatic neurectomy on neuronal number and size distribution in the L7 ganglion of kittens. Exp. Neurol. 74:597-604.

Avellino A.M., Hart D., Dailey A.T., Mackinnon M., Ellegala D. \& Kliot M. 1995. Differential macrophage responses in the peripheral and central nervous system during wallerian degeneration of axons. Exp. Neurol. 36:183-198.

Battiston B., Geuna S., Ferrero M. \& Tos P. 2005. Nerve repair by means of tubulization: literature review and personal clinical experience comparing biological and synthetic conduits for sensory nerve repair. Microsurgery 25(4):258-67.

Be'eri H., Reichert F., Saada A. \& Rotshenker S. 1998. The cytokine network on wallerian degeneration: IL-10 and GM-CSF. Eur. J. Neurosci. 10:27072713.

Brown M.C., Perry V.H., Lunn E.R., Gordon S. \& Heumann R. 1991. Macrophage dependence of peripheral sensory nerve regeneration: Possible involvement of nerve growth factor. Neuron 6:359-370.

Dahlin L.B. 1995. Prevention of macrophage invasion impairs regeneration in nerve grafts. Brain Res. 679:274-280.

Da-Silva C.F., Madison R., Dikkes P., Chiu T.-H. \& Sidman R.L. 1985. An in vivo model to quantify motor and sensory peripheral nerve regeneration using bioresorbable nerve guides. Brain Res. 342:307-315.

Fields D.R. \& Ellisman M.H. 1986. Axons regenerated through silicone tube splices II. Functional morphology. Exp. Neurol. 92:61-74.

Fields D.R., Le Beau J.M., Longo F.M. \& Ellisman M.H. 1989. Nerve regeneration through artificial tubular implants. Prog. Neurobiol. 33:87-134.

Fukuyama R., Takeda H., Fushiki S. \& Yamamoto T. 1998. Muramyl dipeptide injected into crushed sciatic nerve, activates macrophages and promotes recovery of walking locomotion in rats. Restor Neurol Neurosci. 13(3-4):213219.

Hattori A., Tanaka E., Murase K., Ishida N., Chatani Y., Tsujimoto M., Hayashi K. \& Khono M. 1993.Tumor necrosis factor stimulates the synthesis and secretion of biologically active nerve growth factor in non-neuronal cells. J. Biol. Chem. 268:2577-2582.

Hirata K., Mitoma H., Ueno N., He J.W. \& Kawabuchi M. 1999. Differential response of macrophage subpopulation to myelin degradation in the injured rat sciatic nerve. J. Neurocytol. 28:685-695.

Hoffmann J.A., Kafatos F.C., Janeway C.A. \& Ezekowitz R.A. 1999. Phylogenetic perspectives in innate immunity. Science 284:1313-18.

Kiefer R., Kieseier B.C., Stoll G. \& Hartung H.P. 2001. The role of macrophages in immune-mediate damage to the peripheral nervous system. Progr. Neurobiol. 64:109-27.

Lainetti R.D., Pereira F.C. \& Da-Silva C.F. 1995. Reduced sensory neuron regeneration by C57BL/6J mice. Braz. J. Med. Biol. Res. 28:781-785.

Le Beau J.M., Ellisman M.H. \& Powell H.C. 1988. Ultraestructural and 
morphometric analysis of long-term peripheral nerve regeneration through silicone tubes. J. Neurocytol. 17:161-72.

Lindholm D., Heumann R., Meyer M. \& Thoenen H. 1987. Interleukin-I regulates synthesis of nerve growth factor in non-neuronal cells of rat sciatic nerve. Nature 330:658-67.

Liss A.G., Ekenstam F.W. \& Wiberg M. 1996. Loss of neurons in the dorsal root ganglia after transection of a peripheral sensory nerve. Scand. J. Plast. Reconstr. Hand Surg. 30:1-6.

Lu X., Skamene E. \& Richardson P.M. 1994. Studies of axonal regeneration in C57BL/6J and A/J mice. Brain Res. 652:174-176.

Lundborg G. 1988. Nerve regeneration, p.149-195. In: Idem (ed.), Nerve Injury and Repair. Churchill Livingstone, London.

Mackinnon S.E., Dellon A.L., Hudson A., Hunter D.A. \& Seiler W.A. 1984. Chronic nerve compression: an experimental model in the rat. Ann. Plast. Surg. 95:112-20.

Mallat M., Houlgate R., Brachet P. \& Prochiantz A. 1989. Lypopolysaccharidestimulated rat brain macrophages release NGF in vitro. Dev. Biol.133:309311.

Mcllwain D.L. \& Hoke V.B. 2005. The role of the cytoskeleton in cell body enlargement, increased nuclear eccentricity and chromatolysis in axotomized spinal motor neuron. BMC Neurosci. 6:19.

Meyer M., Matsuoka I., Wetmore C., Olson L. \& Thoenen H. 1992. Enhanced synthesis of brain-derived neurotrophic factor in the lesioned peripheral nerve: different mechanisms are responsible for the regulation of BNDF and NGF mRNA. J. Cell Biol. 119:45-54.

Moonis M., Ahmad I. \& Bochhwot B.W. 1992. Macrophages in host defense: an overview. Ind. J. Biochem. Biophys. 29:115-22.

Myles L.M., Gilmour J.A. \& Glasby M.A. 1992. Effects of different methods of peripheral nerve repair on the number and distribution of muscle afferent neurons in rat dorsal root ganglion. J. Neurosurg. 77:457-462.

Nelson E.A.S., Wong Y., Yu L.M., Fok T.F. \& Li K. 2002. Effects of hyperthermia and muramyl dipeptide on IL-1[beta], IL-6, and mortality in a neonatal rat model. Pediatr. Res. 52:886-891.

Ousman S.S. \& David S. 2001. MIP-1a, GM-CSF, and TNF-a control the immune cell response that mediates rapid phagocytosis of myelin from the adult mouse spinal cord. J. Neurosci. 21:4649-4656.

Parant M.A., Parant F.J., Le Contel C., Lefrancier P. \& Chedid L. 1992. MDP derivatives and resistance to bacterial infections in mice. Adv. Exp. Med. Biol. 319:175-184.

Pearse D.D., Pereira F.C. \& Bunge M.B. 2001. Injection of N-acetylmuramyl-1alanyl-d-isoglutamine (MDP) improves histological and behaviorial outcome after contusive spinal cord injury. 31st Annu. Meet. Society for Neuroscience, San Diego, CA, vol.27, p.2042. (Abstract)

Pereira F.C., Lainetti R.D. \& Da-Silva C.F. 1998. Exogenous gangliosides enhance peripheral nerve regeneration. 28th Annu. Meet. Society for Neuroscience, Los Angeles, CA, vol.24, p.1053. (Abstract)

Perry V.H. \& Brown M.C. 1992. Macrophages and nerve regeneration. Curr. Opin. Neurobiol. 2:679-682.

Ramón y Cajal S. 1991. Cajal's degeneration and regeneration of the nervous system. Oxford University Press, London. 976p.

Reichert F., Levitzky R. \& Rotshenker S. 1996. Interleukin-6 in intact and injuried mouse peripheral nerves. Eur. J. Neurosci. 8:530-535.

Ringerbach L., Bohbot A., Tiberghien P., Oberling F. \& Feugeas O. 1998. Polyethilenimine-mediated transfection of human monocytes with the interferon-g gene: an approach to cancer adoptive immunotherapy. Gene Ther. 5:1508-1516.

Rotshenker S. 1997. The cytokine network of wallerian degeneration. Curr. Topics Neurochem. 1:147-156.

Saada A., Reichert F. \& Rotshenker S. 1996. Granulocyte macrophage colony stimulating factor produced in lesioned peripheral nerve induces upregulation of cell surface expression of MAC-2 by macrophages and Schwann cells. J. Cell Biol., 133:159-167.

Schrijver I.A., Van Meurs M., Melief M.J., Ang C.W., Buljevac D., Ravid R., Hazenberg M.P. \& Laman J. D. 2001. Bacterial peptidoglycan and immune reactivity in the central nervous system in multiple sclerosis. Brain 124(8):1544-1554.

Shamash S., Reichert F. \& Rotshenker S. 2002. The cytokine network of wallerian degeneration: tumor necrosis factor-a, interleukin-a, and interleukin-1b. J. Neurosci. 22:3052-3060.

Stoll G., Griffin J.W., Li C.Y. \& Trapp B.D. 1989. Wallerian degeneration in the peripheral nervous system: participation of both Schwann cells and macrophages in myelin degradation. J. Neurocytol. 18:671-683.

Wolfer M.A., Murray T.F., Boons G.J. \& Moore J.N. 2002. The origin of synergistic effect of muramyl dipeptide with endotoxin and peptidoglycan. J. Biol. Chem. 277(42):39179-39186.

Ygge J. 1989. Neuronal loss in lumbar dorsal root ganglia after proximal compared to distal sciatic nerve resection: a quantitative study in the rat. Brain Res. 478:193-195.

Yin Y., Cui Q., Li Y., Irwin N., Fischer D., Harvey A.R. \& Benowitz L.I. 2003. Macrophage-derived factors stimulate optic nerve regeneration. J. Neurosci. 23:2284-2293. 